\title{
PENANAMAN MODAL ASING DI SUMATERA BARAT BERDASARKAN UNDANG-UNDANG NOMOR 25 TAHUN 2007 TENTANG PENANAMAN MODAL
}

\author{
Laurensius Arliman S \\ Sekolah Tinggi Ilmu Hukum Padang, Padang \\ Laurensiusarliman@gmail.com
}

\begin{abstract}
ABSTRAK
Penanaman modal hams menjadi bagian dari penyelenggaraan perekonomian nasional dan ditenrpatkan sebagai upaya nreningkatkan pertumbuhan ekonomi nasional, menciptakan lapangan kerja, meningkatkan pembangunan ekonomi bei-kelanjutan, meniirgkatkair kapasitas dan kemampuan teknologi nasional, mendorong ekonomi 'kerakyatan, mengolah potensi ekonomi petensial menjadi ekonomi riil dengan menggunakan dana yang berasal, 'baik dari dalam negeri marrpun dari, luar negeri, serta meningkatkan kesejahteraan masyarakat. Penanaman modal asing di daerah mempakan salah satu dampak dengarr diberlakukannya Undang-Undang Nomor 25 Tahun 2607 Tentang Penanaman Modal, tulisan ini lrendak menjelaskan bagaimana konsep penanaman modal asing di daeralr serta bagaimana dampak penanaman modal asing di sumatera bar'at. Untuk menjawab hal tersebut, artikel iiri menggunakan penelitiarr yuridis normatif dan juga menghinakan beberapa teori penanaman modal. Sehingga dapat ditemukan suatu jawaban bahwa konsep penanaman modal asing di, daerah, sudah diatur dengan baik didalam undang-undang penanaman modal, namun perlu pengawasan yang lebih baik dari masyarakat, pemerintah dan investor. Ada dampak negatif dan positif dari penanaman modal asing di Sumatera Barat, lral tersebut bisa diatasi asalkan tidak melanggai. aturan yang ada, adat istiadat dan kerifan lokal Sumatera Barat.
\end{abstract}

Kata Kunci: Penananaman Modal Asing ؛Sumatera Barat

\section{ABSTRACT}

Investments should be part oj.the implementation oj the national economy andplacetl in an ejfort to boost national economic growth, create .Jobs, promote sustainable economic development, enhance capacity and national technology, encouraging people's economy, making the economic potential petensial become 'real economy using funds der'ived, botlr domestically and from abroad, as well as improving the welfare oj.society. Foreign investment in. 'the region is one oj' the im.pacts with the enactment ojLaw No. 25 oj.2007 on Investment, this article will explain how tire corrcept oj' foreign investment in the r'egion and how the impact oj'foreign investment in West Sumatra. To answer that, tlris article uses a normative juridical research and also 'Use some investment theory. So you can find an answer' tlrat the concept of foreign investment in tire re.gion is set well within tire. law Is of capita.! investment, but it needs be.tte.r oversight from tire public, government and investor. There are positive and negative i'mpacts of foreign investment in We.st Sumatra, 'it ctrn be overcome as long as it does not violate the existing rules, customs a.nd local wisdom of West Sumatra.. Keywords: Foreign investment; West Sumatra PENDAHULUAN

Penanaman modal asing berperan penting dalam, pemban^inan baik bagi negara maju maupun negara berkembang, begitu juga di Indonesia pada khususnya. Indonesia adalah sebuah negara yang sedang berkembang dalam berbagai aspek pembangunan. Tujuan, dan arah pemban^inan nasional yaitu berusaha mewujudkan suatu masyarakat adil dan makmur, dimana masyarakat yang adil dan makmur itu akan diwujudkan melalui pembangunan di berbagai bidang, di antaranya bidang ekonomi (Aminuddin Ilmar, 2007, 1). Adapun tujuan dan arah pembangunan saat ini lebih terkonsentrasi pada 
aspek ekonomi. Dalam pembangunan ekonomi itu sendiripun membutuhkan para penanam modal yang ingin berinvestasi guna menunjang kenaikan devisa negara. Para penanam modal itupun dapat berasal dari dalam maupun luar negeri, yang penting penanaman modal asing (PMA) tidak melahirkan utang bara (Huala Adolf, 2004, 6).

Penanaman modal sendiri adalah segala bentuk kegiatan menanam modal, baik oleh penanam modal dalam negeri maupun penanam modal luar negeri atau yang lebih dikenal dengan PMA. Kegiatan itu sendiri menggunakan dana yang berasal dari penanam modal tersebut kedalam kegiatan ekonomi. Dalam Undang-Undang Nomor 25 Tahun 2007 Tentang Penanaman Modal (UUPM) disebutkan bahwa: "Tujuan penanaman modal harus menjadi bagian dari penyelenggaraan perekonomian nasional dan ditempatkan sebagai upaya meningkatkan pertumbuhan ekonomi nasional, menciptakan lapangan keija, meningkatkan pembangunan ekonomi berkelanjutan, meningkatkan kapasitas dan kemampuan teknologi nasional, mendorong ekonomi kerakyatan, mengolah potensi ekonomi petensial menjadi ekonomi riil dengan menggunakan dana yang berasal, baik dari dalam negeri maupun dari luar negeri, serta meningkatkan kesejahteraan masyarakat". Untuk menarik para penanam modal tersebut berbagai upaya dilakukan oleh pemerintah. Pada saat ini setiap daerah diberikan hak otonomi untuk mengatur rumah tangganya sendiri namun masih dibawah kontrol pemerintah pusat. Berkaitan dengan itu, dalam pasal 1 ayat (11) UUPM, disebutkan bahwa: "Otonomi daerah adalah hak, wewenang,dan kewajiban daerah otonomi untuk mengatur dan menguras sendiri urusan pemerintahan dan kepentingan masyarakat setempat sesuai dengan ketentuan peraturan perundang- undangan".

Dengan adanya UUPM diharapkan dapat menjadi acuan dalam proses penyelenggaraan modal, serta menjembatani segala kepentingan-kepentingan yang ada, baik itu dari pihak penanam modal maupun penerima modal. Namun pembentukan UUPM itu diharapkan tidak menjadi penghambat proses penanaman modal itu sendiri. Penyelenggaraan penanaman modal hanya dapat tercapai apabila faktor penunjang yang menghambat iklim penanaman modal dapat diatasi, antara lain melalui perbaikan koordinasi antar instansi Pemerintah Pusat dan Pemerintah Daerah, penciptaan birokrasi yang efisien, kepastian hukum di bidang penanaman modal, biaya ekonomi yang berdaya saing tinggi, serta iklim usaha yang kondusif di bidang ketenagakerjaan dan keamanan berusaha. Dengan perbaikan berbagai faktor penunjang tersebut, diharapkan realisasi penanaman modal dapat membaik secara signifikan, sehingga para penanam modal dapat tertarik dan yakin dengan semua faktor penunjang tersebut.

Pemerintah Sumatera Barat pastinya menerapkan hal yang demikian untuk menarik para penanam modal untuk menanamkan modal mereka di daerah Sumatera Barat. Untuk menarik penanam modal tersebut pemerintah Sumatera Barat pada khususnya memberikan kemudahan dengan jalan birokrasi yang lebih mudah, kepastian hukum yang jelas, keterbukaan dan lain-lain dibuat berimbang. Dengan potensi yang ada, pemerintah Sumatera Barat mengupayakan bagaimana agar penanam modal tersebut tertarik untuk menanamkan modal mereka di Sumatera Barat. Pemerintah Sumatera Barat membuka peluang seluas-luasnya tehadap bidang-bidang yang akan dijadikan tempat menanam modal bagi penanam modal tersebut. Sesuai dengan Pasal 12 ayat (1) UUPM menjelaskan tentang bidang usaha yang dapat di jadikan tempat penanaman modal adalah "Semua bidang usaha atau jenis usaha terbuka bagi kegiatan penanaman modal, kecuali bidang usaha atau jenis usaha yang dinyatakan tertutup dan terbuka dengan persyaratan".

Berkaitan dengan hal tersebut, penanaman modal itu hendaknya juga memberikan dampak positif yang lain, sebagai penyelenggaraan perekonomian nasional, berpotensi menciptakan lapangan 
keija, pembangunan ekonomi yang berkelanjutan, meningkatkan daya saing masyarakat daerah sehingga berdaya saing tinggi. Dengan jumlah masyarakat Sumatera Barat yang besar potensi penyerapan tenaga kerja diharapkan dapat dijadikan peluang untuk meningkatkan kesejahteraan masyarakat di Sumatera Barat, peningkatan potensi masyarakat serta peningkatan pengetahuan akan teknologi. Dalam pasal 10 ayat (1) UUPM disebutkan perusahaan penanaman modal dalam memenuhi kebutuhan tenaga kerja harus mengutamakan tenaga kerja warga negara Indonesia. Sedangkan terhadap peningkatan potensi masyarakat dalam pasal 10 ayat (3) UUPM disebutkan perusahaan penanam modal wajib meningkatkan kompetensi tenaga kerja warga negara Indonesia melalui pelatihan kerja sesuai dengan ketentuan peraturan perundang-undangan.

Berdasarkan uraian latar belakang masalah yang dikemukakan diatas maka perumusan masalah dalam penelitian ini adalah sebagai berikut: 1) Bagaimana konsep yang baik terhadap pengaturan penanaman modal asing di daerah? 2) Bagaimana implikasi yang timbul dari diberlakukannya undang-undang penanaman modal terhadap penanaman modal asing di Sumatera Barat?

\section{METODE PENELITIAN}

Penelitian karya ilmiah ini, beijenis penelitian hukum normatif (yuridis normatif) (Zainuddin Ali, 2010, 302). Pada penelitian yuridis normatif penelitian ini difokuskan untuk mengkaji dan meneliti pengaturan penanaman luodal, yaitu meneliti pengaturan penanaman modal asing di Propinsi Sumatera Barat berdasarkan Undang-Undang Nomor 25 Tahun 2007 Tentang Penanaman Modal. Penelitian ini akan melihat nilai ilmiah suatu pembahasan dan pemecahan masalah terhadap legal issue dengan cara pendekatan- pendekatan (approach) yang digunakan, antara lain: 1) Pendekatan Perundang-undangan (Statute Approach). Pendekatan perundang-undangan mempakan suatu hal yang mutlak dalam penelitian yuridis normatif, karena yang akan diteliti adalah berbagai aturan hukum yang menjadi fokus sekaligus tema sentral suatu penelitian (Johnny Ibrahim, 2006, 302). Pendekatan perundangundangan dilakukan deirgan menelaah senrua undang-undang dan regulasi yang bersangkut paut dengan isu hukum yang sedang ditangani; 2) Pendekatan Historis (Historical Approach). Pendekatarr historis dilakukan dalam kerangka pelacakan sejarah lembaga hukum dari wakhi ke waktu. Pendekatan ini sangat membanhi peneliti untuk memahami filosofi dari aturan hukum dari waktu ke waktu. Disamping itu, melallui pendekatan demikian penelitian ini juga dapat memahami perubahan dan perkembangan filosofi yang melandasi aturan hukum tersebut (Johnny Ibrahim., 2006, 206). Penelitian 
normatif yang menggunakan pendekatan sejarah memungkinkan seorang peneliti untuk memahami hukum secara lebih mendalam tentang suatu pengaturan hukum tertentu sehingga dapat memperkecil kekeliruan, baik dalam pemahaman maupun penerapan suatu lembaga atau ketentuan hukum tertentu (Satjipto Raharjo, 1986, 332); dan 3) Pendekatan Kasus (Case Approach). Berbeda dengan penelitian sosial, pendekatan kasus (case approach), dalam penelitian normatif bertujuan untuk mempelajari penerapan norma- norma atau kaidah hukum yang dilakukan dalam praktik hukum (Laurensius Arliman S, 2018, 114). Pendekatan kasus (case approach) tidak sama dengan studi kasus (case study). Dalam pendekatan kasus beberapa kasus ditelaah untuk dijadikan referensi bagi suatu isu hukum. Sedangkan studi kasus (case study), adalah suatu studi terhadap kasus-kasus tertentu dilihat dari berbagai aspek hukum.

\section{HASIL PENELITIAN DAN PEMBAHASAN}

\section{A. Konsep Yang Baik Terhadap Pengaturan Penanaman Modal Asing di Daerah}

Dalam kegiatan penanaman modal asing, penanam modal asing adalah pihak yang terlibat dalam proses penanaman, modal yang mana pihak penanam modal tersebut berasal dari warga negara asing, badan usalra asing, atau pemerintah asing. Adapun pengertian penanaman modal menurut Pasal 1 angka 1 UUPM yaitu: "Peiranaman modal adalah segala benUrk kegiatan menanam motlal, bai.k oleh penanam modal dalam negeri maupun penanam -modal asing unuk melalmkan usaha di wilayah negara Indonesia". Adapun pengertian PMA menurut Pasal 1 angka 3 PMA yaitu: "Penanaman modal asing adalah 'kegiatan menanam modal untuk melalukan usaha di wilayah negara Republik Indonesia yang dilakukan oleh penanam modal asing, baik yang menggunakan modal asing sepenuhnya mattpun yang berpatungan dengan penanam modal dalam negeri".

Pertengahan dasawarsa tahun 1960 merupakan masa suram bagi perkembangan perekonomian Indonesia. Tingkat produksi dan penanaman modal di berbagai selrtor utama menunjukkan kemunduran sejak pertuulaan tahun 1966 bahkan sangat mungkirr lebih rendah dari pada tahun 1938. Sektor industri yang di harapkan uni memacu pertumbuhan ekonomi mengalami penurunan 'bahkan mengalami stagnasi. Hal tersebut menyebabkan dasawarsa tahun mengalami defisit anggaran belanja negai.a mencapai 50\% dari pengeluaran total negara dan mengakibat-kan penerimaan ekspor sangat meirurun, terjadinya hiper inflarrsi dan pada akhirnya mengakibatkan lumpuhnya perekoiromian nasional.

Muhammmad Sadli menguraikan kebijakan ekonomi yang ditempuh olelr penrerintah orde baru pada waktu irn adalah dengan: a) membangun kembali perekonomian di atas prinsip-prinsip ekorromi pasar, perekonomian terbuka, iklim moneter yang stabil serta pembatasan campur tangan dalam kegiatan perekonomian: b) mengubah System ekononri yang alokatif dan distributif menjadi System ekonomi insentif: c) Meransang kaum entrepreneur. untuk mengadakan investasi, inovasi dan produksi melalui mekanisme harga, kebijaksanaan pajak dan tarif, perkreditan dan kebijaksanaan anggaran dan moneter: d) Menarik investasi dan bantuan luar negeri (Moeljarto, 1887, 87).

Terjadinya pergeseran struktur perekonomian secara garis besar dan mengakibatkan strategi pertumbuhan ekonomi nasional yang dijadikan prioritas sasaran oleh pemerintah orde baru. Peranan yang dimainkan oleh modal asing dan bantuan luar negeri juga menjadi faktor penentu dalam laju pertumbuhan ekonomi nasional. Banyaknya industri- industri yang lahir akibat penanaman modal 
khususnya penanaman modal asing serta perbaikan-perbaikan sarana dan prasarana dengan menggunakan bantuan luar negeri merupakan suatu keterikatan yang tidak terbantah bahwa peran yang dimainkan oleh modal asing dan bantuan luar negeri dengan laju perekonomian nasional mengakibatkan terciptanya sarana dan prasarana yang menunjang bagi kehidupan masyarakat Indonesia.

Terlepas dari pendapat pro dan kontra terhadap kehadiran investasi investasi asing, namun secara teoritis kiranya dapat dikemukakan, bahwa kehadiran investor asing di suatu negara mempunyai manfaat yang cukup luas (multiplier effect). Manfaat yang dimaksud yakni kenadiran investor asing dapat menyerap tenaga keija di negara penerima modal, dapat menciptakan demand bagi produk dalam negeri sebagai bahan baku, menambah devisa apalagi investor asing yang berorientasi ekspor, dapat menambah penghasilan negara dari sektor pajak, adanya alih teknologi (transfer of technology) maupun alih pengetahuan (transfer of know how). Dilihat dari sudut pandang ini terlihat bahwa kehadiran investor cukup beiperan dalam pembangunan ekonomi suatu negara, khususnya pembangunan ekonomi di daerah di mana FDI (Foreign Direct Investment) menjalankan aktifitasnya (Sentosa Sembiring, 2007, 23).

Penanaman modal juga di harapkan dapat membantu pemerintah dalam pemecahan masalah lapangan pekerjaan, tingkat pertumbuhan angkatan kerja tiap tahunnya mengalami peningkatan yang cukup tinggi. Selain itu pihak penanam modal juga di harapkan peranannya dalam memperbesar devisa Indonesia lewat ekspor produksinya ke luar negeri. Dari segi manfaat terdapat dua dampak utama dari penanaman modal yang menguntungkan Indonesia. Pertama, meningkatnya pendapatan riil (seperti tertampungnya masyarakat Indonesia sebagai tenaga kerja). Kedua, yaitu adanya manfaat tidak langsung seperti di kenaikannya teknologi dan pengetahuan baru.

Peranan penanam modal asing dalam pelaksanaan pembangunan nasional semakin nyata. Meskipun ditemukan beberapa kelemahan yang sifatnya teknis operasional seperti lemahnya pengawasan aparat yang terkait terhadap pemakaian tenaga kerja asing yang berlebihan dalam suatu perusahaan modal asing dan belum sepenuhnya hasil produknya di ekspor. Perusahaan-perusahaan modal asing pun $\mathrm{w}^{\mathrm{r}}$ ajib mengurus dan mengendalikan perusahaannya sesuai dengan asas-asas ekonomi perusahaan yang tidak merugikan kepentingan negara Indonesia (I.G.Rai Widjaya, 2000, 29).

Dinamika pembangunan nasional memerlukan langkah-langkah pembaharuan di berbagai bidang. Apalagi Indonesia saat ini telah memasuki dekade pembangunan dan berada pada posisi transnasional untuk menuju negara yang maju, aman, adil dan sejahtera. Diperlukan langkah-langkah terhadap kesiapan sumber daya manusia untuk mengantisipasi setiap perkembangan dan perubahan yang terjadi. Oleh karena itu, perlu dirumuskan kerangka dasar dan arah kebijakan pengembangan penanaman modal untuk menopang pertumbuhan ekonomi dan memacu gerak pembangunan nasional. 
Indonesia memiliki potensi sumber daya alam yang relatif besar. Namun jika ditinjau dari implementasi pelaksanaan kebijakan penanaman modal, sumber daya alam, yang dimiliki Indonesia belum memiliki pengolahan secara maksimal dan memadai. Pengolahan potensi ekonomi dapat menghasilkan barang dan jasa. Pengolahan tersebut bukan hanya memerlukan modal yang besar tetapi juga teknologi yang memadai, keterampilan (.skills) dan management yang mana semuanya baru dapat diperoleh apabila suatu pengelolaan potensi ekonomi memiliki kucuran modal yang besar yaitu melalui kegiatan penanaman modal termasuk penanaman modal asing. Pemerintah mungkin saja dapat melakukan hal tersebut sendiri, namun karena keterbatasan modal, teknologi, kemampuan akan keterampilan serta management secara rasional penanaman modal memerlukan keterlibatan pihak lain untuk mendukung dan membantu pengelolaan tersebut.

Mencermati potensi sumber daya alam yang dimiliki dan bentuk pengelolaan yang belum maksimal, otomatis memberikan potensi yang cukup besar dan memungkinkan penanam modal untuk mengembangkan potensi yang dimilikinya. Berbagai bentuk kebijakan yang ditawarkan untuk menjamin dan mempermudah pelayanan dan perizinan penanaman modal dan hal tesebut ikut menjadi salah satu daya tarik bagi pengembangan penanaman modal di masa depan. Prospek pengembangan penanaman modal khususnya penanaman modal asing sangatlah menjanjikan. Namun, pemerintah harus mampu membuat berbagai kebijakan yang mendukung kegiatan ekonomi secara $f$ air dan adil serta tetap memprioritaskan kepentingan Indonesia didalamnya. Menjanjikan Indonesia sebagai salah satu negara tujuan penanaman modal tidaklah sulit jika ekonomi nasional negara stabil, keamanan dapat terjaga dengan baik dan kepastian hukum dapat diciptakan..

Pengembangan penanaman modal asing sangat dibutuhkan untuk mendorong dan memacu perkembangan penanaman modal di Indonesia. Kebijakan yang dibuat untuk mengatur penanaman modal bukanlah dimaksud untuk mempersempit ruang jangkauan dalam melakukan usaha tetapi justru memberikan perlindungan hukum yang lebih memadai dan menciptakan sinergitas hubungan dengan negara penerima modal (host country) agar lebih serasi dan berimbang dalam perolehan hasil. UUPM dinyatakan berlaku sejak diundangkan dalam Lembaran Negara Republik Indonesia Tahun 2007 Nomor 67 pada tanggal 26 April 2007. Dengan lahirnya UUPM secara tidak langsung menggantikan undang-undang tentang penanaman modal yang lama yaitu, Undang- undang Nomor 1 Tahun 1967 tentang Penanaman Modal Asing dan Undang-undang Nomor 6 Tahun 1968 tentang Penanaman Modal Dalam Negeri yang sudah digunakan selama lebih kurang empat puluh tahun. Pada hakekatnya jika dikaji jauh kebelakang cita-cita bangsa Indonesia adalah kebebasan untuk hidup mandiri membangun masyarakat adil dan makmur diatas bumi Indonesia yang kaya berbagai sumber daya alam. Cita-cita bangsa Indonesia merupakan cita-cita luhur bangsa yang terpatri dalam pembukaan Undang-Udang Dasar 1945.

UUPM menjelaskan bahwa latar belakang dikeluarkannya Undang-undang ini adalah dengan menimbang sebagai berikut: a) bahwa untuk mewujudkan masyarakat adil dan makmur berdasarkan Pancasila dan Undang-Undang Dasar Negara Republik

Indonesia Tahun 1945 perlu dilaksanakan pembangunan ekonomi nasional yang berkelanjutan dengan berlandaskan demokrasi ekonomi untuk mencapai tujuan bernegara; b) bahwa sesuai dengan amanat yang tercantum dalam Ketetapan Majelis Permusyawaratan Rakyat Republik Indonesia Nomor XVI/MPR/1998 tentang Politik Ekonomi dalam rangka Demokrasi Ekonomi, kebijakan penanaman modal selayaknya selalu mendasari ekonomi kerakyatan yang melibatkan pengembangan bagi usaha mikro, kecil, menengah, dan koperasi; c) bahwa untuk mempercepat pembangunan ekonomi nasional dan mewujudkan kedaulatan politik dan ekonomi Indonesia 
diperlukan peningkatan penanaman modal untuk mengolah potensi ekonomi menjadi kekuatan ekonomi riil dengan menggunakan modal yang berasal, baik dari dalam negeri maupun dari luar negeri; d) bahwa dalam menghadapi perubahan perekonomian global dan kcikutseitaan Indonesia dalam berbagai kerja sama internasional perlu diciptakan iklim penanaman modal yang kondusif, promotif, memberikan kepastian hukum, keadilan, dan efisien dengan tetap memperhatikan kepentingan ekonomi nasional; e) bahwa Undang-Undang Nomor 1 Tahun 1967 tentang Penanaman Modal Asing sebagaimana telah diubah dengan Undang-Undang Nomor 11 Tahun 1970 tentang Perubahan dan Tambahan Undang-Undang Nomor 1 Tahun 1967 tentang Penanaman Modal Asing dan Undang-Undang Nomor 6 Tahun 1968 tentang Penanaman Modal Dalam Negeri sebagaimana telah diubah dengan Undang-Undang Nomor 12 Tahun 1970 tentang Pembahan dan Tambahan Undang-Undang Nomor 6 Tahun 1968 tentang Penanaman Modal Dalam Negeri perlu diganti karena tidak sesuai lagi dengan kebutuhan percepatan perkembangan perekonomian dan pembangunan hukum nasional, khususnya di bidang penanaman modal;

\section{B. Dampak Yang Timbul Dari Diberlakukannya Undang-Undang Penanaman Modal Terhadap Penanaman Modal Asing Di Sumatera Barat.}

Jika berbicara lebih lanjut tentang dampak yang timbul dari diberlakukannya UUPM terhadap Penanaman Modal Asing di Sumatera Barat, maka terlebih dahulu kita tinjau pengaruh dari undang-undang ini secara nasional. Lahirnya UUPM tentu saja membawa dampak terhadap sektor perekonomian di Indonesia, apakah itu dampak positif maupun dampak negatif. Namun sepeiti yang kita ketahui suatu perundang- undangan maupun peraturan yang dibuat oleh pemerintah selalu bertujuan positif yaitu demi kepentingan bangsa dan negara sehingga membawa kesejahteraan yang nantinya dirasakan oleh rakyatnya. Sebelum lahirnya UUPM, semua kegiatan yang berkaitan dengan kegiatan penanaman modal khususnya penanaman modal asing dapat dikatakan belum memiliki pengaturan terbaru yang dapat mengakomodasi segala kepentingan penanaman modal dan menjadi titik tolak yang dapat diandalkan untuk mewujudkan pembangunan ekonomi nasional yang berkelanjutan dengan berlandaskan demokrasi ekonomi untuk mencapai tujuan negara yang telah dicita-citakan dalam Pancasila dan Undang-Undang Dasar 1945.

Ini tidak berarti kegiatan penanaman modal asing di Indonesia selama ini tidak memiliki pengaturan, tetapi pengaturan yang sudah ada sebelum UUPM dianggap sudah tidak mengikuti perkembangan kegiatan penanaman modal yang ada saat ini. Jadi lahirnya UUPM ini diharapkan dapat menjadi sekat pengaturan sekaligus upaya

pemerintah untuk menarik para penanam modal khususnya penanam modal asing untuk melakukan kegiatan penanaman modal di Indonesia. Pada UUPM ini juga di jelaskan prosedur penanaman modal, jaminan kepastian hukum, hak, kewajiban serta tanggung jawab penanam modal yang membantu efektifitas kegiatan penanaman modal di Indonesia, serta mengatur penanaman modal dalam negeri dan penanaman modal asing di Indonesia sehingga lebih terarah dan teratur dalam pelaksanaannya.

Oleh karena itu, untuk memahami secara utuh apa yang terkandung dalam UUPM yaitu UUPM A perlu dicermati bahwa lahirnya undang-undang ini tidak dapat dilepaskan dari perkembangan masyarakat, khususnya komunitas pelaku usaha yang demikian dinamis, baik dari dalam negeri maupun luar negeri. Hal ini juga di tunjang dengan masa sekarang ini yang lebih dikenal sebagai era globalisasi, yang mana arus perputaran modal pun dengan demikian cepat berpindah dari satu tempat ketempat lain.

Gebrakan dari perubahan yang terdapat dalam ketentuan UUPM khususnya pada penanaman modal asing sebelumnya yaitu Undang-undang Nomor 1 Tahun 1967 tentang Penanaman Modal Asing 
adalah: 1) Pada UUPM yang terbaru ini dijelaskan pengaturan mengenai pengembangan penanaman modal bagi usaha mikro, kecil, menengah dan koperasi (terdapat dalam pasal 13 UUPM); 2) Penjelasan yang lebih spesifik tentang hak, kewajiban, dan tanggung jaw ${ }^{\mathrm{r}} \mathrm{ab}$ penanam modal (terdapat dalam pasal 14 UUPM); 3) Apresiasi tersendiri yang diberikan oleh pemerintah bagi penanam modal (terdapat dalam pasal 18 angka 3 UUPM); 4) Masa perizinan Hak Atas Tanah yang diperpanjang (terdapat dalam pasal 22 UUPM); 5) Pelayanan terpadu yang bertujuan untuk membantu penanam modal dalam memperoleh kemudahan pelayanan, fasilitas fiskal dan informasi mengenai penanam modal (terdapat dalam pasal 26 UUPM); 6) Penyelenggaraan penanaman modal berdasarkan asas otonomi daerah dan tugas pembantuan serta dekonsentrasi (terdapat dalam pasal 27 UUPM); 7) Badan Koordinansi Penanaman Modal sebagai badan koordinasi pelaksana kebijakan penanaman modal (terdapat dalam pasal 27); 8) Adanya pemberlakuan Kawasan Ekonomi Khusus (terdapat dalam pasal 33 UUPM).

Berbicara lebih lanjut tentang pengaruh UUPM terhadap prosedur penanaman modal yang teijadi di Sumatera Barat, maka lebih dahulu kita tinjau pengaruh keberadaan UUPM ini secara umum. Lahirnya UUPM tentu saja membawa pengaruh terhadap dunia perekonomian di Indonesia, apakah itu pengaruh positif maupun pengaruh negatif. Namun jika dilihat tujuan dari lahirnya suatu peraturan perundang- undangan selalu bertujuan positif yaitu demi kepentingan bangsa dan negara.

Sebelum lahirnya UUPM semua kegiatan penanaman modal bisa dikatakan berjalan dengan peraturan yang sudah tidak sesuai lagi dengan kondisi saat sekarang ini. Ini bukan berarti peraturan yang ada sebelum dikeluarkannya UUPM tidak mengatur tentang penanaman modal. Dengan berlakunya UUPM, maka investor yang ingin menanamkan modalnya di Indonesia diharapkan akan lebih mudah dan semakin berminat untuk berinvestasi. Hal ini disebabkan oleh karena prosedur dalam penanaman modal di Indonesia sudah mengalami perombakan guna memberikan daya tarik kepada investor serta diberikannya berbagai fasilitas oleh pemerintah sebagai wujud keseriusan pemerintah untuk menarik investor untuk berinvestasi ke Indonesia. Walaupun aturan 
mengenai pedoman dan tata cara pemohonan penanaman modal sudah ada dengan di keluarkannya Keputusan Menteri Investasi/ Kepala BKPM melalui Keputusan Menteri Investasi/Kepala Badan Koordinasi Penanaman Modal Nonror 38 Tahun 1999 tentang Pedoman dan Tata Cara Permohonan Penanaman Modal Yang Didirikan Dalam Rangka Penanaman Modal Dalam Negeri dan Penanaman Modal Asing. Tetapi lahirnya UUPM adalah tetap merupakan produk hukum terbaru yang mengatur penanaman modal baik penanaman modal dalam negeri maupun penanaman modal asing.

Mengenai prosedur penananran modal di Sumatera Barat dapat dittraikan sebagai berilmt: Calon investoi. mendatangi kantor BKPM Provinsi Sumatera Barat di Padang untuk mencari infonnasi tentang bidang usaha apa yairg akan menjadi tempat tujuan investasi. Bila bidang usaha tersebut tidak masuk kedalam Daftar Negatif Investasi, berarti bidang usaha yang akan menjadi tempat ftrjuan investasinya tersebut terbuka atau boleh dilakukan penanaman modal terlradapnya. Setelah itu oleh bagian perencanaan si Investor diberi model I PMDN/model I PMA, yang pada model I PMA dicantumkan komposisi kepemilikan saham asing dan saham dari pen^^rsaha lokal. Model i.ni haius diisi dengan benar, sebab bila terjadi kesalalian yang disengaja unmk kepentingan si calon investoi' maka terhadap calon investor tersebut dapat dikenakan sanksi. Disamping hartts mengisi model tersebut, calon invest-or hartts pula melengkapi persyaratan aplikasi sesuai dengan SK Nomor 57 Tahun 2004 Tentang Pedoman Tata Cara Pelaksanaan Permohonan Penanaman Modal yaitu: a) Akte pendirian perusahaan yag berbenUik badan hukum dengan mencantumkan sektor bidang usaha yang bersangtoan; b) Nomor Pokok Wajib Pajak (NPWP); c) Uraian proses produksi; dan d) Pencegalran peirccmaran lingkungan.

Disamping hal diatas ada pula persyaratan khusus: a) Unftlk badan usaha: 1) Neraca Talrun Terakhir (Koperasi); 2) BUMN berbentuk persero. Persetujuan Menteri Keuairgan atas rencana Investasi; 3) BUMN berbentuk perusahaan umum. Persetujuan Menteri teknis yang bersangkutan; dan 4) Perusahaan Daerah, Persetujuan Gubernur Kepala Daerah Tingkat Provinsi: b) Bidang usaha pertambangan. Melampirkan surat izin penambangan daerah (SIPD) / kuasa pertambangan (KP), Bidang pertanian menggunakan areal harus ada keputusan Menteri Keliutanan. Bidang usaha tertutup dalam Daftar Negatif Investasi untuk hasil produksinya di ekspoi.. (Melampirkan pernyataan pembeliair yang diketahui olelr Kedutaan Besar. Negara yang bersangkutan).

Setelah model I PMDN/model I PMA ini diis'i olelr calon investor, nraka oleh BKPM Provinsi Sumatera Bar - at permohonan itu dibawa dalam rapat koordinasi dengan mengundang instansi yang terkait. Bila rapat koordinasi rrrenganggap tidak ada pernrasalalran maka permohonan itu dikirim ke BKPM Pusat dalam 7 ratrgkap unftrk mendapatkan surat persetujuan. BKPM Pusat mengadakan rapat lagi dengan mengrrndang Departemen terkait. Apabila permohonan itu disetujui maka oleh BKPM Pusat menerbitkan suatu surat persetujuan yang dikirim kepada investor, yang bersangkutan dan kepada BKPM Prophrsi Sumatera Barat.

Bagi Pr-opinsi Sumatera Barat lahirnya Undang-undarrg Nomor- 25 Tahun 2007 tentang Penanaman Modal juga membawa pengaruh, terutama sekal.i dalarrr memperoleh izin bagi calon investor yang akarr menanamkan modalrrya di provinsi Sumatera Barat meliputi: a) Izin Mendirikan Bangunan (IMB); b) Izin Lokasi; dan c) Izin Undang- undang lingkungan (tempat usaha (HO).

Perolehan izin seperti; Izin Mendirikan Bangunan (IMB), Izin Lokasi, Izin Undang-undang lingkungan (tempat usaha/HO) diatas telah diberikan kewenangan perizinannya kepada Kabupaten/Kota. Prosedur yang harus dilalui oleh investor yang akan menanamkan modalnya di provinsi Sumatera Barat sehubungan dengan izin mendirikan bangunan adalah berdasarkan PERDA 
masing-masing Kabupaten/Kota di provinsi Sumatera Barat tentang mendirikan/ memperbaiki, merombak bangunan dalam provinsi Sumatera Barat, prosedur tersebut yaitu : Setiap orang atau badan swasta maupun publik yang akan mendirikan, memperbaiki/ merombak bangunan harus mengajukan permohonan izin kepada Bupati/ Walikota yang ada didalam wilayah provinsi Sumatera Barat dan pekerjaan baru dapat dikerjakan apabila izin yang dimaksud sudah diperoleh.

Bagi setiap orang atau badan swasta/perusahaan yang ingin berusaha di Kabupaten/Kota yang ada di wilayah Sumatera Barat haruslah memperoleh izin lokasi dimana tempat diadakannya usaha tersebut dilakukan. Untuk wilayah provinsi Sumatera Barat izin lokasi dan izin Undang-undang lingkungan/tempat usaha (HO) disatukan saja prosedur pengurusannya. Surat keputusan mengenai izin lokasi dan izin tempat usaha (HO) ini dinamakan surat keputusan tentang pemberian izin tempat usaha yang mencakup di dalamnya izin lokasi dan izin Undang-undang lingkungan/tempat usaha(HO).

Demikianlah dampak positif lahirnya UUPA terhadap prosedur penanaman modal yang ditemui di provinsi Sumatera Barat. Dimana setiap pengusaha yang akan menanamkan modalnya mendirikan perusahaannya didaerah provinsi Sumatera Barat harus melalui prosedur yang telah diuraikan diatas, seperti memperoleh Izin Mendirikan Bangunan, Izin Lokasi/Izin tempat Usaha (HO). Dampak negatif lahirnya UUPA boleh dikatakan sedikit sekali terhadap prosedur penanaman modal, oleh karena pembuatan UUPA justru bertujuan untuk mempermudah prosedur penanaman modal itu sendiri, sehingga bisa meningkatkan minat pengusaha untuk menanamkan modalnya di Indonesia.

Kebijaksanaan Pemerintah dalam memberikan peluang usaha bagi dunia usaha merupakan dorongan bagi penumpukan modal karena si pengusaha akan tertarik dengan peraturan perundangundangan yang dikeluarkan oleh pemerintah. Untuk mengundang minat pengusaha dalam menanamkan modalnya di Indonesia pada umumnya dan di provinsi Sumatera Barat, pemerintah memberikan kemudahan-kemudahan dalam melakukan investasi dalam bidang-bidang usaha yang ditentukan, seperti kemudahan- kemudahan dibidang perizinan, meliputi izin usaha, izin bangunan, izin undang-undang bangunan, dan kemudahan-kemudahan dibidang prosedur penanaman modal yang dilaluinya. Dalam hal bidang usaha ini pemerintah dengan Keputusan Presiden mengeluarkan Daftar Negatif Infestasi. Daftar Negatif Investasi (DNI) ini mengemukakan bidang-bidang usaha yang tertutup bagi PMDN dan PMA dan tertutup untuk bidang-bidang usaha di luar. Undang-undang PMDN dan PMA sesuai dengan Peraturan Presiden Nomor 77 Tahun 2007 Tentang Daftar Bidang Usaha Yang Tertutup dan Bidang Usaha Yang Terbuka Dengan Persyaratan Di Bidang Penanaman Modal yang kemudian di sempurnakan dengan dikeluarkannya Peraturan Presiden Nomor 111 Tahun 2007 tentang Perubahan Atas Peraturan Presiden Nomor 77 Tahun 2007.

Maksud dari Daftar Negatif Investasi (DNI) adalah untuk memudahkan para penanam modal untuk memilih bidang usaha yang diminati dengan memberikan keleluasaan yang sebesar-besarnya dengan tujuan untuk menggairahkan iklim investasi yang pada gilirannya akan dapat meningkatkan kegiatan investasi baik dalam rangka PMDN maupun dalam rangka PMA. Untuk merangsang minat pengusaha dalam menanamkan modalnya, pemerintah mengadakan kemudahan-kemudahan dan fasilitas- fasilitas yang dapat mendorong minat pengusaha dalam mendirikan usahanya. Langkahlangkah ini diambil secara teipadu untuk menggairahkan iklim dunia usaha Indonesia, baik berasal dari PMDN maupun PMA.

Penanaman modal yang mendapat fasilitas-fasilitas yang diberikan oleh pemerintah sekurangkurangnya harus memenuhi salah satu kriteria: a) Penanam modal baru; b) Melakukan perluasan usaha; c) Menyerap banyak tenaga keija; d) Masuk skala prioritas tinggi; e) Termasuk pembangunan infrastruktur; f) Melakukan alih teknologi; g) Melakukan industri pionir; h) Berada didaerah terpencil, 
daerah tertinggal, daerah perbatasan; i) Menjaga kelestarian lingkungan hidup; j) Melaksanakan kegiatan penelitian, pengembangan, dan inovasi; k) Bermitra dengan usaha mikro, kecil, menengah, atau koperasi; 1) Industri yang menggunakan barang modal atau mesin yang diproduksi di dalam negeri.

Adapun fasilitas-fasilitas yang disediakan untuk para investor yang akan menanamkan modalnya di Indonesia antara lain adalah: a) Pengurangan pajak penghasilan melalui pengurangan penghasilan netto sampai tingkat tertentu terhadap jumlah penanaman modal yang dilakukan dalam waktu tertentu; b) Pembebasan atau keringanan bea masuk atas impor barang modal, mesin, atau peralatan untuk keperluan produksi yang belum dapat diproduksi didalam negeri; c) Pembebasan atau keringanan bea masuk bahan baku atau bahan penolong untuk keperluan produksi untuk jangka waktu tertentu dan persyaratan tertentu; d) Pembebasan atau penangguhan Pajak Pertambahan Nilai atas impor barang modal atau mesin atau peralatan untuk keperluan produksi yang belum dapat diproduksi didalam negeri selama jangka waktu tertentu; e) Penyusutan atau amortisasi yang dipercepat; dan f) Keringanan Pajak Bumi dan Bangunan, khususnya untuk bidang usaha tertentu, pada wilayah atau daerah atau kawasan tertentu.

Adapun pada fasilitas pengurangan Pajak Penghasilan dalam jangka waktu tertentu hanya diberikan pada penanam modal baru yang merupakan industri pionir, yaitu industri yang memiliki keterkaitan yang luas, memberikan nilai tambah dan eksternalitas yang tinggi, memperkenalkan teknologi baru, serta memiliki nilai strategis bagi perekonomian nasional. Selain fasilitas yang tersebut, Pemerintah juga memberikan kemudahan pelayanan dalam perizinan kepada penanam modal untuk: a) Hak atas tanah; b) Fasilitas pelayanan keimigrasian; c) Fasilitas perizinan impor. Pemerintah juga memberikan perpanjangan waktu terhadap perizinan hak atas tanah, seperti: a) Hak Guna Usaha (HGU); b) Hak Guna Bangunan (HGB); dan c) Hak Pakai (HP)

Dari penjabaran diatas dapat dilihat bahwa ada perbedaan mengenai pengaturan hak pakai, sehingga timbulnya dualisme ketentuan peraturan perundang-undangan. Didalam IJUPM pemberian fasilitas hak pakai tersebut diberikan selama 70 tahun, sedangkan dalam UUPA pemberian fasilitas tersebut dapat diberikan secara terus menerus selama tanah untuk keperluan tertentu masih dipergunakan atau bahkan justru diberikan secara cuma-cuma. Jika dikaji kedua ketentuan perundangundangan tersebut maka dapat menimbulkan keraguan dan terkesan membingungkan. Bagaimana mungkin ketentuan perundang-undangan yang dibuat pada satu negara dengan mengedepankan tujuan yang sama yaitu mewujudkan pembangunan yang menyeluruh bagi segenap rakyat Indonesia justru memiliki perbedaan yang bersebrangan yang mencolok. Sehingga jika muncul keraguan dalam kegiatan penanaman modal maka timbul masalah yaitu peraturan manakah yang lebih relevan untuk dipakai dalam kegiatan penanaman modal tersebut, terutama yang berkenaan dengan hak guna usaha, hak guna bangunan, dan hak pakai.

Oleh sebab itu marilah kita jabarkan kembali tentang landasan fundamental dari undangundang yaitu berupa asas prinsipil yang menjadi pertimbangan dalam cikal bakal pembuatan sebuah undang-undang yaitu meliputi: a) Asas Lex Spesiale Derogat Legi Generale (undang-undang khusus mengenyampingkan undang-undang yang bersifat umum). Asas ini memberi arti bahwa apabila adanya suatu peraturan yang sama terhadap suatu ketentuan yang diatur oleh dua buah undang-undang, maka ketentuan dari undang-undang khusus yang akan diberlakukan dengan mengenyampingkan ketentuan dari undang-undang yang bersifat umum; b) Asas Lex Superior Derogat Legi Priori (undang-undang yang lebih tinggi mengenyampingkan undang-undang yang lebih rendah). Asas ini jika dilihat dari tata urutan perundang-undangan yang mana dalam tatanannya perundang-undangan 
disusun dari hierarki yang paling tinggi sampai yang paling rendah. Jadi dengan kata lain perundangundangan yang urutannya dibawah tidak boleh bertentangan dengan perundang-undangan yang lebih tinggi; c) Asas Lex Posterior Derogat Legi Anteriori (undang-undang yang berlaku kemudian membatalkan undang-undang yang berlaku sebelumnya). Asas ini berlaku dan baru dapat diterapkan apabila terjadi pembahan undang-undang yang mana undang-undang yang baru mengatur persoalan yang sama dengan yang diatur pada undang-undang terdahulu sebelumnya sedangkan undang-undang yang baru tidak ada secara eksplisit membatalkan undang-undang yang bam atau undang-undang berlaku kemudian; d) Asas Legalitas, Secara teoritis ketentuan tentang asas ini lebih diatur dalam ketentuan hukum pidana yaitu melalui pasal 1 ayat 1 KUHP yang menyatakan bahwa: "Tiada suatu perbuatan dapat dipidana kecuali diatas kekuatan aturan pidana dalam perundang- undangan yang telah ada sebelum perbuatan dilakukan."

Berdasarkan asas-asas diatas maka sudah jelaslah bahwa UUPM lah yang lebih patut diterapkan dalam pelaksanaan kegiatan penanaman modal, khususnya yang berkenaan dengan hak guna usaha, hak guna bangunan, dan hak pakai. Namun setelah Mahkamah Konstitusi Republik Indonesia mengeluarkan keputusan dan memutuskan bahwa pengaturan tentang hak guna usaha, hak guna bangunan, dan hak pakai dikembalikan kepada peraturan yang di atur didalam UUPA. Jadi tidak ada lagi keraguan akan peraturan undang-undang mana yang digunakan dalam kegiatan

penanaman modal tersebut khususnya tentang hak guna usaha, hak guna bangunan, dan hak pakai tersebut.

Fasilitas atas perizinan tentang hak guna usaha, hak guna bangunan dan hak pakai yang terdapat didalam kegiatan penanaman modal tersebut diberikan dan dapat diperpanjang sekaligus yang maksudnya jika: a) Penanaman modal tersebut dilakukan dalam jangka waktu yang panjang; b) Penanaman modal memiliki tingkat resiko yang tinggi sehingga penanaman modal tersebut membutuhkan waktu yang lama untuk pengembalian modal; c) Penanaman modal tersebut tidak memerlukan lahan atau areal yang luas; d) Penanaman modal tersebut menggunakan hak atas tanah Negara; e) Penanaman modal tidak mengganggu kepentingan umum.

Dengan adanya kemudahan-kemudahan serta fasilitas-fasilitas seperti diuraikan di atas, maka diharapkan dapat menarik minat pengusaha untuk menginvestasikan modalnya didalam bidang usaha yang di minatinya. Untuk Provinsi Sumatera Barat dengan potensi daerah yang dimiliki telah dapat menarik minat para investor dalam negeri maupun investor asing untuk dapat menanamkan modalnya di wilayah Sumatera Barat. Hal ini terlihat dengan semakin meningkatnya jumlah investor yang menanamkan modalnya di Sumatera Barat. Misalnya rencana pembangunan tempat usaha di bidang pariwisata, petambangan, hotel dan lain-lain.

\section{KESIMPULAN}

Undang-Undang Nomor 25 Tahun 2007 Tentang Penanaman Modal telah menberikan pengaruh dalam menciptakan iklim investasi yang lebih baik dan diharapkan dengan adanya UUPM ini dapat mengakomodasi segala kepentingan investasi dan menjadi titik tolak ukur yang dapat dihandalkan guna mewujudkan pembangunan ekonomi Nasional yang berkelanjutan dengan berlandaskan demokrasi ekonomi untuk mencapai tujuan bernegara yang telah dicita-citakan sebagaimana yang terdapat dalam Pancasila dan Undang-Undang Dasar 1945. Terlepas dari pendapat pro dan kontra terhadap kehadiran investasi investasi asing, namun secara teoritis kiranya dapat dikemukakan, bahwa kehadiran investor asing di suatu negara mempunyai manfaat yang cukup luas 
(multiplier effect). Manfaat yang dimaksud yakni kehadiran investor asing dapat menyerap tenaga kerja di negara penerima modal, dapat menciptakan demand bagi produk dalam negeri sebagai bahan baku, menambah devisa apalagi investor asing yang berorientasi ekspor, dapat menambah penghasilan negara dari sektor pajak, adanya alih teknologi (transfer of technology) maupun alih pengetahuan (transfer of know how). Dilihat dari sudut pandang ini terlihat bahwa kehadiran investor cukup berperan dalam pembangunan ekonomi suatu negara, khususnya pembangunan ekonomi di daerah, sehingga konsep pengaturan perusahaan modal asing di daerah sudah cukup baik, namun didalam penerapannya perlu pengawasan yang baik antara para pihak yang bersangkutan, baik itu masyarakat, pemerintah ataupun investor. Sedangkan dalam penanaman modal asing di Provinsi Sumatera Barat pelaksanaannya berlansung dengan teratur sesuai dengan prosedur, peningkatan minat berinvestasi bagi pengusaha PMDN maupun PMA, serta pengawasan dan pengendalian modal yang lebih terkontrol, sehingga pada akhirnya menimbulkan 

pengaruh positif terliadap perkembangan penanaman modal dan kesejahteraan masyarakat di Provinsi Sumatera Barat, walaupun ada dampak negatif, hal ini bisa ditutupi asalkan tidak melanggar aturan yang telah ditetapkan oleh pemerintah, tidak melanggar adat dan juga kearifan lokal di Sumatera Barat sendiri.

\section{DAFTAR PUSTAKA}

\section{A. Buku}

Aminuddin Ilmar, 2007. Hukum Penanaman Modal Indonesia. Jakarta: Prenada Media.

AniigaPi $\lfloor!$, |ע̃ע. Perusahaan Multi Nasional dan Penanaman Modal Asing, iarta.. Pustaka Jaya.

Erman Rajagukguk, 1995, Hukum Investasi (BaJuin Kuliah), Jakarta: UI Press.

WmVa Aii, HA. Perjanjian Penanaman Moda.1 dalanr Hukum Perdagangan Internasional (WTO. Jakarta: Raja Grafindo Persada.

l.G.Wai 2 - ذ. Penanaman Modal Pedoman Prosedur Mendirikan dan Menjalankan Perusahaan Dalam Rangka PMA dan PMDN. Harta... تע إ|هة| Paramita.

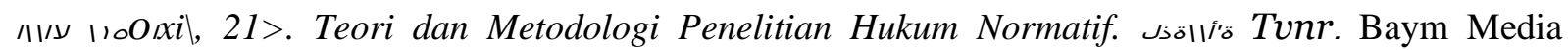
Publishing.

Lili, Rasjidi, 1988. Filsafat Hukum. Bandung: CV Remaja Karya.

Muhammad Sadli dalam Mocljarto, 1887. Politik Pembangunan: Sebuah Analisis Konsep, Arah dan Strategi. Yogyakarta: Tiara Wacana.

M. Sornarajah, 2010. The International Law on Foreign Investment. Cambridge: Cambridge University Press.

Satjipto Raharjo, 1986. Ilmu Hukum. Bandtmg: Alumni Bandung.

$\wedge$ do\rav $• 1$. Hukum Investasi: Pembahasan Dilengkapi Dengan Undangundang Nomor 25 Tahun 2007 Tentang Penanaman Modal. Widig.. 1 قأهلآ Aulia.

Zainuddin Ali, 2010. Metode Penelitian Hukum. Jakarta: Sinar Grafika

B. Jurnal dan Disertasi

Laurensius Arliman s, 2018. Peranan Metodologi Penelitiair Hukum Di Dalam Perkembangan Ilmu Hukum Di Indonesia. Jumal Soumatera Law Review, 1(1').

Mahmul, Siregar, 2017. Undang- Undang Penanaman Modal dan PenyelesaianSengketa Perdagangan Internasional Dalam Kegiatan Penanaman Modal. Jumal Hukum Bisnis, 26(4).

IdvanA, Ziav, 15. Penerapan Prinsip-prinsip Hukum Internasional Penanaman Modal Asing di Indonesia. Disertasi, Program Pasca Sarjana Universitas Airlangga. 
Nindyo Pramono, 2006. Perkembangan Arus Investasi Ditinjau Dan Perspektif Hukum Bisnis. Jurnal Legislasi Indonesia, 3(1).

\section{Data Internet}

Adriansyah, Teori-Teori Hukum Investasi dan Penanaman Modal, lihat dalam: https://customslawyer.wordpress.com/2014/06/26/teori-teori-hukum-investasi-danpenanaman-modal/ 